Tropical Journal of Pharmaceutical Research April 2015; 14 (4): 663-669

ISSN: $1596-5996$ (print); 1596-9827 (electronic)

(C) Pharmacotherapy Group, Faculty of Pharmacy, University of Benin, Benin City, 300001 Nigeria.

All rights reserved.

Available online at http://www.tjpr.org

Original Research Article

http://dx.doi.org/10.4314/tjpr.v14i4.15

\title{
Development and Validation of Reversed Phase High Performance Liquid Chromatographic Method for Determination of Amlodipine
}

\author{
Mohamed Alaama ${ }^{1,2}$, ABM Helal Uddin ${ }^{1 *}$, Huda Jamilah Mohamad ${ }^{1}$, Noor \\ Syafawati Amiruddin ${ }^{1}$ and SA Abbas ${ }^{3}$ \\ ${ }^{1}$ Analytical and Bio-Analytical Research Laboratory, Department of Pharmaceutical Chemistry, Faculty of Pharmacy, \\ International Islamic University Malaysia (IIUM), Jalan Istana, Bandar Indera Mahkota, 25200 Kuantan, Pahang, Malaysia, \\ ${ }^{2}$ Department of Food and Analytical Chemistry, Faculty of Pharmacy, Aleppo University, Aleppo, Syria, ${ }^{3}$ School of Pharmacy, \\ Taylors University, 1 Jalan Taylor's, 47500 Subang Jaya, Selangor Darul Ehsan, Malaysia
}

*For correspondence: Email: mohdhelal@hotmail.com, abmhelal@iium.edu.my

Received: 4 July 2014

Revised accepted: 17 February 2015

\begin{abstract}
Purpose: To develop and validate a new sensitive and low-cost method for the analysis of amlodipine in tablet dosage form using reversed phase high performance liquid chromatography (RP-HPLC) with ultraviolet (UV) detection.

Methods: Standards and samples were prepared by dissolving amlodipine besylate standard or amlodipine tablets in mobile phase and sonicated for $5 \mathrm{~min}$. The samples were analysed by RP-HPLC equipped with quaternary pump and auto-injector. Separation was achieved using C18 column, and the mobile phase consisted of ammonium acetate buffer containing $0.02 \%$ triethylamine TEA $(\mathrm{pH}=4$, adjusted using glacial acetic acid) and acetonitrile in the ratio 60:40 v/v. The flow rate was $1 \mathrm{ml} / \mathrm{min}$ and a UV detector was used for the detection of amlodipine at a wavelength of $248 \mathrm{~nm}$. The method was validated according to International Conference of Harmonization (ICH) guidelines.

Results: The retention time for amlodipine peak was $3.44 \pm 0.41$ min with a total run time of 6 min. The method was linear over the range of $0.5-40 \mu \mathrm{g} / \mathrm{ml}$ with coefficient of determination $\left(R^{2}\right)$ of 0.999 . Recovery was 98.09 - $100.19 \%$, and the method showed high precision and repeatability. All validated parameters were within the range of $\mathrm{ICH}$ requirements.

Conclusion: A new rapid sensitive and low-cost method has been developed and validated for the analysis of amlodipine in tablet dosage form.
\end{abstract}

Keywords: Amlodipine, Recovery, Repeatability, Precision, Reversed phase high performance liquid chromatography, Validation

Tropical Journal of Pharmaceutical Research is indexed by Science Citation Index (SciSearch), Scopus, International Pharmaceutical Abstract, Chemical Abstracts, Embase, Index Copernicus, EBSCO, African Index Medicus, JournalSeek, Journal Citation Reports/Science Edition, Directory of Open Access Journals (DOAJ), African Journal Online, Bioline International, Open-J-Gate and Pharmacy Abstracts

\section{INTRODUCTION}

Amlodipine, 2-[(2-Aminoethoxy)methyl]-4-(2chlorophenyl)-1,4-dihydro-6-methyl-3,5-

pyridinedicarboxylic acid 3-ethyl 5-methyl ester, a third generation dihydropyridine calcium antagonist. It is used in the treatment of hypertension and coronary artery disease (CAD) such as chronic stable angina, vasospastic angina (Prinzmetal's or Variant Angina) and angiographically-documented CAD [1]. It was firstly formulated by Pfizer under the brand name of Norvasc, but several generic versions are now available. Amlodipine was combined with several drugs in order to enhance their activities or to combine more activities. 
Literature review shows different analytical methods for the analysis of amlodipine in pharmaceutical preparations or biological fluids either as a single drug or in combination with other drugs. Those analytical methods include: spectrophotometric methods with or without derivatization [2-7]. The derivative spectroscopy has also been applied for the determination of amlodipine and its photodegradant compound [8]. Chromatographic methods have been used widely for the analysis of amlodipine, including thin layer chromatography (TLC) methods [9-12] and HPLC methods $[13,14]$. Capillary electrophoresis methods were also used for the analysis of amlodipine in its formulations and biological fluids $[15,16]$. Amlodipine was also determined using liquid chromatography mass spectrometry (LC-MS) [17,18]. .

One of the most important requirements to prepare any new formula for existed drugs is to develop and validate an analytical method for the analysis of the drug in bulk and finished product. Some existed methods were tested for the analysis of new amlodipine tablet produced but they were found not to fulfil the requirements. Some of the low-cost methods reported before have low sensitivity, whereas the highly-sensitive methods are costly. The aim of this study was to develop and validate a new, low-cost, highlysensitive and specific HPLC method for the analysis of amlodipine in tablets dosage form.

\section{EXPERIMENTAL}

All the chemicals were of analytical grade and the solvents were HPLC grade. Amlodipine besylate USP standard with potency of $99.8 \%$ was purchased from Sigma. Acetonitrile, methanol, phosphoric acid, and triethylamine were obtained from Fisher Scientific. Ammonium acetate, glacial acetic acid, sodium hydroxide, hydrochloric acid, hydrogen peroxide, were all purchased from Merck. All solvent were filtered using vacuum filtration unit Sartoriuse (Sartorius Goettingen, Germany) with Nilon filters (0.45 $\mu \mathrm{m})$. Mettler Toledo (USA) analytical balance was used. The $\mathrm{pH}$ of the buffers was monitored using Mettler Toledo $\mathrm{pH}$ meter.

\section{Chromatographic conditions}

HPLC (Agilent Technologies USA) equipped with Agilent 1200 series quaternary pump and vacuum degasser, an Agilent 1200 series autoinjector with 0.1 - $100 \mathrm{uL}$ variable volume injector and an Agilent 1200 series variable wavelength detector (VWD). Data processing was performed using HP Chem-Station software. The samples were injected to the $\mathrm{C} 18$ Hypersil $(3.5 \mu \mathrm{m}, 2.1 \times 100 \mathrm{~mm})$ column and the mobile phase consisted of ACN: Ammonium acetate buffer $0.05 \mathrm{M}$ containing $0.02 \%$ TEA (40:60 v/v) and the $\mathrm{pH}$ of the buffer was adjusted to $\mathrm{pH}=4$ using glacial acetic acid. The flow rate was 1 $\mathrm{ml} / \mathrm{min}$ and the detection of amlodipine besylate was monitored using UV detector at $248 \mathrm{~nm}$ wavelength.

\section{Method development}

\section{Standard preparation}

A stock solution of amlodipine with the concentration of $1 \mathrm{mg} / \mathrm{ml}$ was prepared by transferring $13.87 \mathrm{mg}$ of amlodipine besylate (equivalent to $10 \mathrm{mg}$ of amlodipine) into $10 \mathrm{ml}$ volumetric flask and $2 \mathrm{ml}$ of mobile phase was added and sonicated for $5 \mathrm{~min}$ and then cooled to the room temperature. The solution was diluted to the mark using mobile phase. Further dilutions with mobile phase were prepared to obtain suitable calibration curve standard in the linear range of $0.5-40 \mu \mathrm{g} / \mathrm{ml}$.

\section{Sample preparation}

To prepare the tablet samples, 10 tablets were weight and grounded and then the equivalence weight of one tablet was transferred into $10 \mathrm{ml}$ volumetric flask and mixed with $5 \mathrm{ml}$ of mobile phase. The mixture was sonicated for $20 \mathrm{~min}$, cooled to the room temperature and then the volume was brought to $10 \mathrm{ml}$ using mobile phase. The mixture was mixed thoroughly and then filtered using Whatman filter paper no. 1. Further dilution was carried out using mobile phase before injection.

All stock solutions were kept in a refrigerator under $4{ }^{\circ} \mathrm{C}$ and they were stable for three months under such conditions.

\section{Chromatographic analysis}

Samples were analysed using Agilent 1200 Series RP-HPLC equipped with quaternary pump and auto injector. UV detector was used for the detection, and the wavelength was $248 \mathrm{~nm}$.

Different types of column C8 and C18 were tested to choose the best for the analysis. All chromatographic parameters were evaluated for better separation, including mobile phase 
composition, $\mathrm{pH}$, flow rate and column temperature.

\section{Method validation}

The developed method was validated according to ICH guidelines [19] to ensure specificity, linearity, range, accuracy, precision, limit of detection (LOD), limit of quantitation (LOQ) and robustness of the method

\section{Forced degradation studies}

Forced degradation studies of the drug substance can help identify the likely degradation products, the stability and specificity of the analytical procedure.

\section{Acid degradation studies}

A volume of $9 \mathrm{ml}$ of $0.1 \mathrm{M}$ hydrochloric acid solution was added to $1 \mathrm{ml}$ of amlodipine standard stock solution or to $1 \mathrm{ml}$ of tablet stock solution. These solutions were divided into three parts and maintained under 4,50 , and $90{ }^{\circ} \mathrm{C}$, the portions were allowed to stand for 6 days and analysed at intervals over $120 \mathrm{~h}$ after dilution to $10 \mu \mathrm{g} / \mathrm{ml}$ and neutralization using $\mathrm{NaOH}$.

\section{Alkali degradation studies}

Sodium hydroxide $0.1 \mathrm{M}$ was used for alkali degradation study. A volume of $9 \mathrm{ml}$ of sodium hydroxide was added to $1 \mathrm{ml}$ of amlodipine standard stock solution or to $1 \mathrm{ml}$ of tablet stock solution. These solutions were divided to three parts and maintained at 4,50 , and $90{ }^{\circ} \mathrm{C}$; the portions were allowed to stand for 6 days and analysed at intervals over $120 \mathrm{~h}$ after dilution to $10 \mu \mathrm{g} / \mathrm{ml}$ using mobile phase and neutralization using $\mathrm{HCl}$.

\section{Oxidization degradation studies}

A volume of $9 \mathrm{ml}$ of $3 \%$ hydrogen peroxide was added to $1 \mathrm{ml}$ of amlodipine standard stock solution or tablet stock solution. These solutions were divided to three parts and maintained at 4, 50 , and $90{ }^{\circ} \mathrm{C}$, the portions were allowed to stand for 6 days and analysed at intervals over $120 \mathrm{~h}$ after dilution to $10 \mu \mathrm{g} / \mathrm{ml}$.

\section{Temperature stress studies}

A $1 \mathrm{ml}$ of amlodipine standard stock solution or Amlodipine besylate tablet with concentration of $1 \mathrm{mg} / \mathrm{ml}$ of amlodipine besylate were maintained at 4,50 , and $90{ }^{\circ} \mathrm{C}$ for 6 days and analysed at intervals over $120 \mathrm{~h}$.

\section{Statistical analysis}

All data were derived from at least three independent experiments. Statistical analysis of the data was carried out using Microsoft Excel 2010.

\section{RESULTS}

\section{Chromatographic conditions}

The optimized chromatographic conditions were as follow: the column was C18 Hypersil $(3.5 \mu \mathrm{m}$, $2.1 \times 100 \mathrm{~mm}$ ) as it gave the best peak shape and the highest reproducibility and repeatability. Mobile phase was ACN: Ammonium acetate buffer $0.05 \mathrm{M}(40: 60 \mathrm{v} / \mathrm{v})$ with $\mathrm{pH}=4$ adjusted using glacial acetic acid. The detector used in this study was UV/Vis, the wavelength was set at $\lambda=248 \mathrm{~nm}$ to reduce the noise which is generated by using lower wavelengths. The elution was performed at $30{ }^{\circ} \mathrm{C}$ with flow rate of 1 $\mathrm{ml} / \mathrm{min}$. The retention time (RT) of amlodipine under these conditions was $3.4 \mathrm{~min}$ and the full run time was optimized to $6 \mathrm{~min}$; Figure 1.

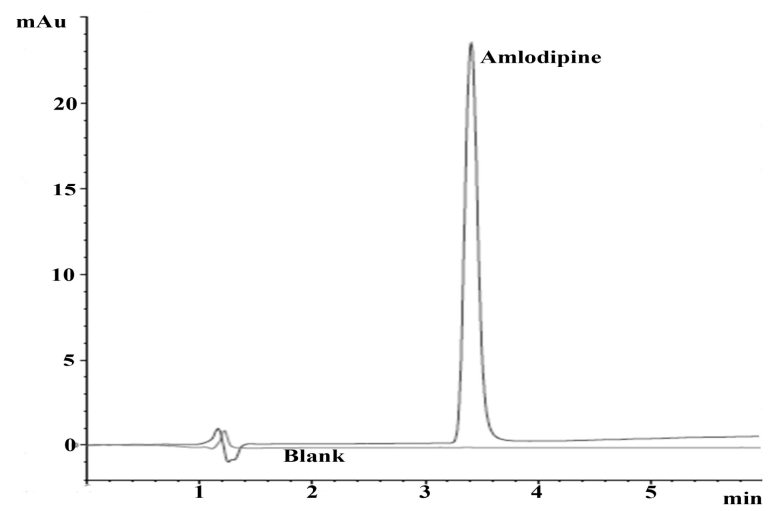

Figure 1: Chromatograms obtained from amlodipine besylate and placebo (blank)

\section{Validation results}

\section{Specificity}

The specificity of the method was determined by injecting the sample solution containing the placebo which was prepared by mixing the excipients without the amlodipine using same amount as the tablet. The method was specific for amlodipine upon running the placebo and degradation study. The results showed no interference from the excipients as shown in Figure 1. The results of forced degradation studies revealed no interference with the degradants peaks also. 


\section{Linearity}

Linearity solutions were prepared at 7 concentration levels from $2.5 \%$ to $200 \%$ of analyte concentration. The method was linear over the range of $0.5-40 \mu \mathrm{g} / \mathrm{ml}$ with linear regression equation of $y=9.6362 x-1.7689$ and a coefficient of determination $\mathrm{R}^{2}$ of 0.999 .

\section{Accuracy}

The accuracy of the method was carried out by spiking known amount of amlodipine besylate at seven concentration levels ranging from $50 \%$ and $150 \%$ of the label claim along with the excipients in triplicate. Samples were prepared following the sample preparation method described above. The recovered amounts were in the range of 98.1 - $100.19 \%$ which is within the acceptable range according to $\mathrm{ICH}$ guidelines. The accuracy and recovery results are presented in Table 1.

\section{Precision}

Repeatability, intra-day and inter-day precision studies were carried out to ensure the precision of the method. Precision of the method was checked by carrying out six independent assays of amlodipine besylate test samples against the standard. For repeatability and intraday precisions, six replicate of standard solutions were injected within same day, while for inter-day precision, the samples were injected in different days. Two parameters were evaluated for precision studies which are area and retention time of the peak. The results are shown in Table 2.
Table 2: Precision (repeatability, inter-day and intraday) results

\begin{tabular}{lcc}
\hline Parameter & Concentration & $\begin{array}{c}\text { Retention time } \\
\text { (min) }\end{array}$ \\
\hline Repeatability & 1.028 & 0.186 \\
Intra-day RSD & 1.187 & 0.416 \\
Inter-day RSD & 1.408 & 0.318 \\
\hline
\end{tabular}

\section{Limit of detection (LOD) and of quantification (LOQ)}

LOD and LOQ were calculated using the slope and standard deviation of standard curve for low concentrations of amlodipine. LOD was 17.2 $\mathrm{ng} / \mathrm{ml}$ while LOQ was $52.3 \mathrm{ng} / \mathrm{ml}$.

\section{System suitability}

System suitability parameters were evaluated according to $\mathrm{ICH}$ guidelines such as USP tailing factor, plate number and capacity factor. The RSD for repeated sample run was evaluated also according to USP method for amlodipine. Table 3 shows the results for system suitability parameters and they are all within the acceptable range for $\mathrm{ICH}$ and USP guidelines.

\section{Forced degradation studies}

The results showed that amlodipine standard and amlodipine tablet were stable under room temperature, acid hydrolysis, base hydrolysis and solvent effect conditions as shown in Figure $3 \mathrm{a}, 3 \mathrm{~b}$, and $3 \mathrm{c}$. The results also revealed that amlodipine standard and tablet are stable under $50{ }^{\circ} \mathrm{C}$ using base hydrolysis as it appears in Figure $3 \mathrm{~b}$. It is indicated in the results that both standard and tablets followed the same path of degradation up to $48 \mathrm{~h}$ indicating that the

Table 1: Accuracy and recovery of amlodipine in spiked samples

\begin{tabular}{lccccccc}
\hline \multirow{2}{*}{ Drug } & \multicolumn{7}{c}{ Concentration } \\
\cline { 2 - 7 } & $\mathbf{5 0 \%}$ & $\mathbf{7 0 \%}$ & $\mathbf{8 0 \%}$ & $\mathbf{1 0 0 \%}$ & $\mathbf{1 2 0 \%}$ & $\mathbf{1 3 0 \%}$ & $\mathbf{1 5 0 \%}$ \\
\hline $\begin{array}{l}\text { Amount added } \\
(\mathrm{mg})\end{array}$ & 5 & 7 & 8 & 10 & 12 & 13 & 15 \\
$\begin{array}{l}\text { Amount } \\
\text { recovered }(\mathrm{mg})\end{array}$ & 4.928 & 7.0135 & 8.011 & 9.815 & 11.808 & 12.752 & 14.715 \\
$\begin{array}{l}\text { Actual content } \\
(\%)\end{array}$ & 98.551 & 100.193 & 100.140 & 98.150 & 98.405 & 98.096 & 98.106 \\
RSD & 1.884 & 1.787 & 0.998 & 0.786 & 0.924 & 0.257 & 0.480 \\
\hline
\end{tabular}

Table 3: System suitability parameters results of amlodipine standard

\begin{tabular}{lcccc}
\hline $\begin{array}{l}\text { System suitability } \\
\text { parameter }\end{array}$ & USP tailing factor & $\begin{array}{c}\text { Plate count } \\
\text { number }\end{array}$ & $\begin{array}{c}\text { Capacity factor } \\
\text { K }\end{array}$ & $\begin{array}{c}\text { RSD for peak area } \\
\text { for repeated run }\end{array}$ \\
\hline Accepted range & $1.022<2$ & $2791>2000$ & $5.880>2$ & $1.028<2$ \\
\hline
\end{tabular}


excipients have no effect on the degradation of amlodipine in tablet form. After $48 \mathrm{~h}$ and the excipients showed some effect in the degradation process of amlodipine in tablet form using acid and solvent effect degradation and this effect appeared significantly after $120 \mathrm{~h}$ as shown in Figure 3a and 3c. For oxidization, about $50 \%$ of amlodipine was degraded after $30 \mathrm{~h}$ under 4 and $50{ }^{\circ} \mathrm{C}$ (Figure $3 \mathrm{~d}$ ). Under $90^{\circ} \mathrm{C}$, full degradation was achieved using oxidization after $2 \mathrm{~h}$ (Figure $3 \mathrm{~d}$ ), while it needed $120 \mathrm{~h}$ to degrade the whole amlodipine under acid, base and solvent degradation as it is shown in Figure 3a, $3 \mathrm{~b}$ and $3 \mathrm{c}$.

\section{Application of proposed method to commercial products}

The method was applied for three commercial products which are: amlodine (S.Y.P. Malaysia),
Vamlo (Ranbaxy) and iAmlo (formulated inhouse at IIUM Pilot Plant). The samples were prepared according to sample preparation method described in experimental section and analyzed using the developed method. The results were shown in Table 4 and they were comparable with the reference method [1].

\section{DISCUSSION}

Among others, amlodipine is one of the products which has been studied for the quality control issues. This study was designed to develop and validate suitable in house analytical method for the analysis of amlodipine in the new formulation. From the results it can be claimed that the developed method was specific, accurate and reproducible. The detector used in this study was UV/Vis detector which
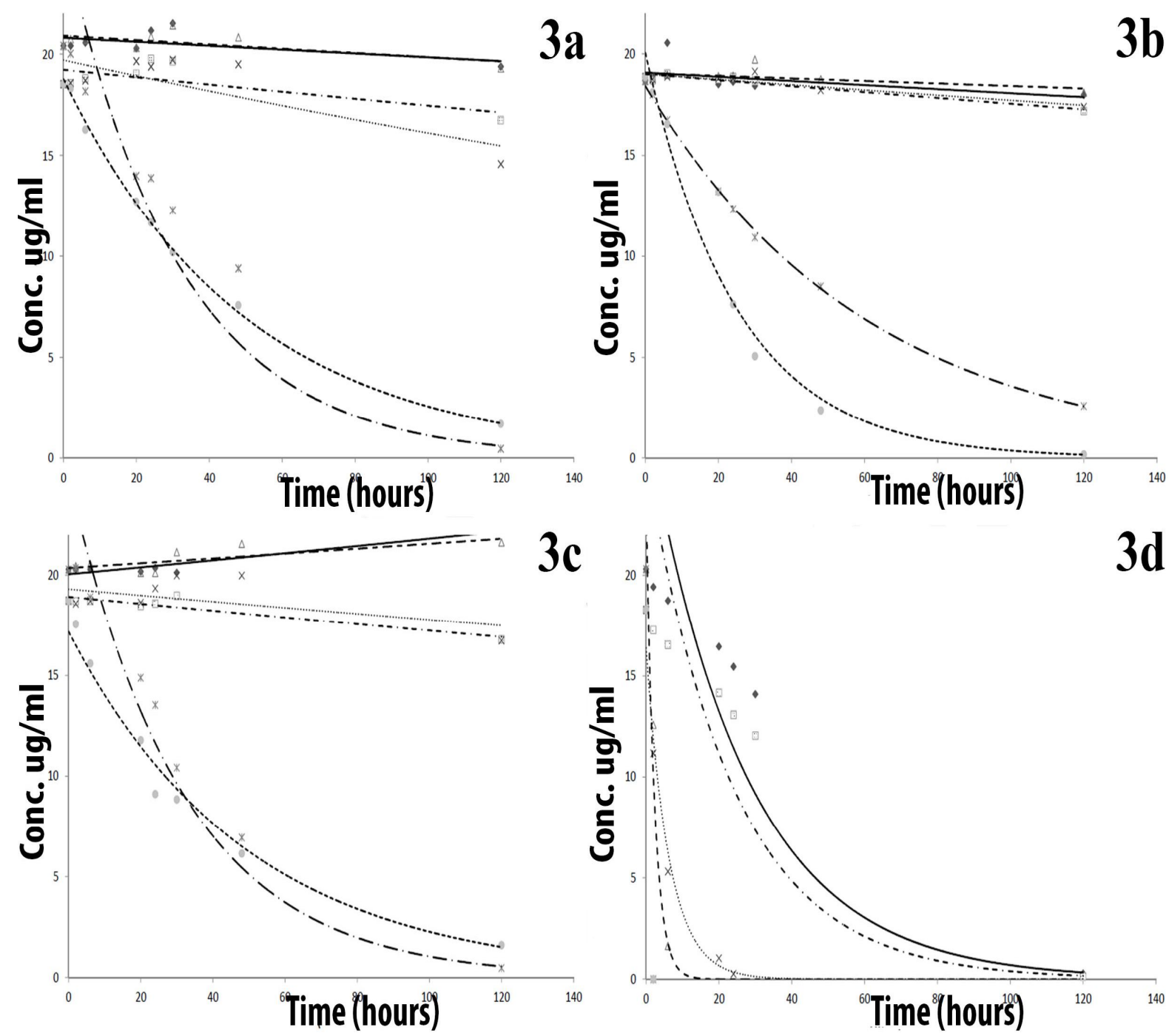

Figure 3: Forced degradation profiles for amlodipine standard and tablet under varying conditions: $\bullet, \triangle$ and * standard at 4,50 and $90^{\circ} \mathrm{C} ; \square, \mathrm{X}$, ○ tablets at 4,50 and $90^{\circ} \mathrm{C}$ 
Table 4: Assay results for the determination of amlodipine in three commercial formulations

\begin{tabular}{|c|c|c|c|c|c|}
\hline \multirow{2}{*}{\multicolumn{2}{|c|}{ Dosage form }} & \multirow{3}{*}{$\begin{array}{c}\begin{array}{c}\text { Labeled } \\
\text { amount (mg) }\end{array} \\
10\end{array}$} & \multirow{2}{*}{$\begin{array}{c}\text { Proposed method } \\
\begin{array}{c}\text { Amount } \\
\text { found (mg) }\end{array}\end{array}$} & \multirow{3}{*}{$\begin{array}{c}\begin{array}{c}\text { Amount } \\
\text { found (\%) }\end{array} \\
99.470\end{array}$} & \multirow{2}{*}{$\begin{array}{c}\text { Reference method } \\
\text { Amount } \\
\text { found (\%) }\end{array}$} \\
\hline & & & & & \\
\hline \multirow{4}{*}{$\begin{array}{l}\frac{0}{\frac{D}{0}} \\
\frac{\text { O을 }}{\frac{1}{4}}\end{array}$} & Sample 1 & & 9.947 & & \\
\hline & Sample 1 & 10 & 9.884 & 98.840 & \\
\hline & Sample 3 & 10 & 9.763 & 97.630 & \\
\hline & Mean(SD) & & $9.865(0.076)$ & 98.650 & \\
\hline \multirow{4}{*}{$\begin{array}{l}\frac{O}{E} \\
\frac{\mathbb{E}}{N}\end{array}$} & Sample 1 & 5 & 5.027 & 100.540 & \\
\hline & Sample 1 & 5 & 4.930 & 98.610 & \\
\hline & Sample 3 & 5 & 4.925 & 98.500 & \\
\hline & Mean(SD) & & $4.961(0.047)$ & 99.220 & \\
\hline \multirow{4}{*}{$\frac{\text { 을 }}{\frac{1}{\leq}}$} & Sample 1 & 10 & 9.774 & 97.740 & 97.020 \\
\hline & Sample 1 & 10 & 10.315 & 103.150 & 99.360 \\
\hline & Sample 3 & 10 & 10.022 & 100.220 & 98.920 \\
\hline & Mean(SD) & & $10.036(0.220)$ & 100.360 & $98.430(1.020)$ \\
\hline
\end{tabular}

ensures that the method is low-cost, and also that high reproducibility achieved. LOD and LOQ results from this study were comparable with those achieved using sophisticated technology. The method was linear over the range of $0.5-40$ $\mu \mathrm{g} / \mathrm{ml}$ with $\mathrm{R}^{2}$ of 0.999 and the linearity was evaluated for lower concentrations to find LOD in the range of $0.1-5 \mu \mathrm{g} / \mathrm{ml}$ with $\mathrm{R}^{2}=0.999$.

The method was evaluated for precision and reproducibility and the results were in the accepted range of $\mathrm{ICH}$ guidelines. The method was robust upon using different instruments or columns. The forced degradation studies showed that amlodipine is stable against acid and base hydrolysis in room temperature and $50{ }^{\circ} \mathrm{C}$, while it is totally unstable due to oxidization by $\mathrm{H}_{2} \mathrm{O}_{2}$. Comparison of the results obtained in this study with results from reference methods indicate that this method is highly accurate and robust.

\section{CONCLUSION}

A robust, accurate, economic and precise method has been developed and validated according to $\mathrm{ICH}$ guidelines and is suitable for routine analysis of amlodipine in solid dosage forms.

\section{ACKNOWLEDGEMENT}

The authors expressed their gratitude to staff of IIUM Pharmaceutical Manufacturing Plant and Department of Pharmaceutical Chemistry, Faculty of Pharmacy, International Islamic University Malaysia for their help and support. This research was supported by grant no. EDW B 13-062-0947 from Research Management Center, International Islamic University Malaysia,
IIUM. Grant no. SP11-003-0071 from Malaysian Ministry of Finance and grant RACE no. 140014-0020 from Ministry of Education (MOE).

\section{REFERENCES}

1. The British Pharmacopoeia, VII. Her Majesty's Stationery Office. 2008, London, UK.

2. Belal SF, Haggag RS, Shaalan RAA. The Use of an Aromatic Substitution Reaction in the Spectrophotometric Determination of Selected Amino or Thiol Containing Drugs. J Food Drug Anal, 2008; 16(1): 26-33.

3. Bernard $S$, Mathew $M$, Senthilkumar $K L$. Spectrophotometric method of estimation of Amlodipine besylate using hydrotropic solubilization. J Appl Pharm Sci, 2011; 1(09): 177-180.

4. Derayea SM, Askal HF, Abdel-Megeed OH, El-Hamd MA. Spectrophotometric determination of amlodipine and nicardipine in pharmaceutical formulations via binary complex formation with eosin Y. J Appl Pharm Sci, 2012; 2(06): 84-89.

5. Mishra P, Shah K, Gupta A. Spectrophotometric methods for simultaneous estimation of nebivolol hydrochloride and amlodipine besylate in tablets. Int $\mathrm{J}$ Pharm Pharm Sci, 2009; 1(2): 55-61.

6. Patil PR, Rakesh SU, Dhabale $P$, Burade $K$. Simultaneous UV Spectrophotometric Method for Estimation of Losartan Potassium and Amlodipine Besylate in Tablet Dosage Form. Asian J. Research Chem, 2009; 2(1): 183-187.

7. Rahman N, Nasrul Hoda M. Validated spectrophotometric methods for the determination of amlodipine besylate in drug formulations using 2,3-dichloro 5,6-dicyano 1,4-benzoquinone and ascorbic acid. J Pharm Biomed Anal, 2003; 31(2): 381-392.

8. Ragno G, Garofalo A, Vetuschi C. Photodegradation monitoring of amlodipine by derivative 
spectrophotometry. J Pharm Biomed Anal, 2002; 27(1-2): 19-24.

9. Argekar A, Powar S. Simultaneous determination of atenolol and amlodipine in tablets by highperformance thin-layer chromatography. J Pharm Biomed Anal, 2000; 21(6): 1137-1142.

10. Dhaneshwar SR, Patre NG, Mahadik MV. Validated TLC Method for Simultaneous Quantitation of Amlodipine Besylate and Valsartan in Bulk Drug and Formulation. Chromatographia, 2009; 69(1): 157-161.

11. Meyyanathan S, Suresh B. HPTLC method for the simultaneous determination of amlodipine and benazepril in their formulations. J Chromatogr Sci, 2005; 43(2): 73-75.

12. Patel DB. Simultaneous Estimation of Amlodipine Besylate and Indapamide in Pharmaceutical Formulation by Thin-Layer ChromatographicDensitometric method. Novel Science-IJPS , 2012; 1(2).

13. Chitlange S, Bagri K, Sakarkar D. Stability indicating RPHPLC method for simultaneous estimation of valsartan and amlodipine in capsule formulation. Asian J. Res. Chem, 2008; 1: 15-18.

14. El-Gizawy SM, Abdelmageed OH, Omar MA, Deryea SM. Development and Validation of HPLC Method for Simultaneous Determination of Amlodipine,
Valsartan, Hydrochlorothiazide in Dosage Form and Spiked Human Plasma. AJAC, 2012; 3(6): 422-430.

15. Alnajjar AO. Validation of a Capillary Electrophoresis Method for the Simultaneous Determination of Amlodipine Besylate and Valsartan in Pharmaceuticals and Human Plasm. J AOAC Int, 2011; 94(2): 498-502.

16. Mikus P, Marakova K, Marak J, Nemec I, Valaskova I, Havranek E. Pharmacokinetic Study of Amlodipine in Human Urine Using On-Line Coupled Isotachophoresis-Capillary Zone Electrophoresis with Diode Array Detection. Curr Pharm Anal, 2009; 5(2): 171-178.

17. Bhatt J, Singh S, Subbaiah G, Shah B, Kambli S, Ameta $S$. A rapid and sensitive liquid chromatographytandem mass spectrometry (LC-MS/MS) method for the estimation of amlodipine in human plasma. Biomed Chromatogr, 2007; 21(2): 169-175.

18. Karra V, Pilli N, Inamadugu J, Rao J. Simultaneous determination of losartan, losartan acid and amlodipine in human plasma by LC-MS/MS and its application to a human pharmacokinetic study. Pharm Methods, 2012; 3(1): 18.

19. ICH. 'Validation of analytical procedures: text and methodology Q2 (R1) 2005. International Conference on Harmonisation of Technical Requirements for Registration of Pharmaceuticals for Human Use. 